\title{
The shifting territorialities of the Rhone River's transboundary governance: a historical analysis of the evolution of the functions, uses and spatiality of river basin governance
}

\author{
Christian Bréthaut • Géraldine Pflieger
}

Received: 15 May 2013/Accepted: 30 September 2013/Published online: 12 October 2013

(C) Springer-Verlag Berlin Heidelberg 2013

\begin{abstract}
For the past decade, water policies have been strongly influenced by the concept of integrated water resource management (IWRM), and the river basin has been regarded as the most relevant scale for water governance. This article is based on the case of the Rhone River. Through historical analysis (from 1870 to the present), we study how the river's functions evolve, how water users compete to secure their needs, and the effects on the governance structure and on its spatiality. While this governance structure has remained stable for decades, we show how the evolution of water policies (and the emergence of IWRM) and of environmental concerns strongly modified the strategies of actors. We also demonstrate how the governance structure as well as its space and scale of regulation tends to change with the attempt of central States to get back to the centre of the configuration of actors.
\end{abstract}

Keywords Water governance $\cdot$ Functional regulatory space $\cdot$ IWRM $\cdot$ Rhone $\cdot$ Hydroelectricity

\section{Introduction}

For the two countries-Switzerland and France-and the different cantons and regions located along its banks, the Rhone River has long been considered a major development factor. The Swiss part of the Rhone is mainly used for agriculture upstream from Lake Geneva and for hydropower production in Geneva where the management of the river is delegated to a semipublic hydropower company,

C. Bréthaut $(\varangle) \cdot$ G. Pflieger

Institute for Environmental Sciences, University of Geneva, Geneva, Switzerland

e-mail: christian.brethaut@unige.ch the SIG (Services Industriels de Genève). On the French side of the river, since 1933, the CNR (Compagnie Nationale du Rhône) is in charge of its management from the Swiss border to the Mediterranean Sea. The company has three missions: hydropower production, navigation and irrigation. Since the beginning of the 2000s, the emergence of new water management perspectives (IWRM for example), the implementation of the European Union's water framework directive and the strengthening of environmental legislation and concerns modified the arena of governance of the Rhone. While on both sides of the border, the management of the river was partly delegated to hydropower companies, and public stakeholders tend to look for new ways of managing the whole basin.

This article deals with the current debates and shift in the management of the Rhone River and its territoriality. It aims to discuss the issues related to the transboundary governance of the river when its flow has historically been governed through hydropower production. More specifically, it deals with three questions:

1. How have the territorialities of river management evolved since the nineteenth Century?

2. What is the impact of these various territorialities on uses and users, both in terms of inclusion and exclusion?

3. And reciprocally, to what extent has the emergence of new uses, and users, challenged the territorial governance of the river?

After a review of the state of the art and description of our analytical framework, and the presentation of our methodology, we will analyse the three phases of the Rhone River's governance since the nineteenth century and how the territorial governance of the river evolved along with changes in water uses. Finally, in the final section, we 
will discuss the results of our analysis of the three questions mentioned above.

\section{State of the art and analytical framework}

Since the end of the 1990s, the concept of integrated water basin management or integrated river basin management has spread worldwide under the auspices of the United Nations, NGOs and natural scientists in order to (1) emphasise the need for coordination between users sharing the same water resource and (2) promote the basin scale as the relevant scale of managing resources. This has also been transcribed in the EU water framework directive of 2000, which set the river basin scale as the best model to promote (Barraqué 2001; Barraqué 2009; Graefe 2011). In this context of deep institutional reform, several authors (Young 2002; Moss 2003; Moss and Jens 2010; Ostrom 1999, 2010) have emphasised a number of problems linked to the disconnection between the different spaces and the multiple institutional levels of environmental problems. These problems are related (1) to the scalar misfit between environmental processes and institutional levels, (2) to the scalar interplay (both vertically and horizontally) between different institutional levels, which could be responsible for the management of a resource (Young 2002), and (3) to the reconfiguration of scalar levels of responsibilities linked to rescaling processes, and, for instance, the emergence of new institutional levels dedicated to resources management (Nahrath et al. 2009), such as river basin institutions (Moss 2003). The main contribution of those authors working on the "politics of scale" (Swyngedouw 2004; Brenner 2004) is to have emphasised the strategic use of scales made by public actors and the potential impact of rescaling processes on the interplay between pre-existing institutions and on the distribution of power.

Within the theoretical and empirical discussion of environmental rescaling processes, we propose in this paper a more detailed discussion of the territorialities and geographical boundaries of river basin governance. We define the notion of territoriality as a controlled, bounded area, providing a means of reifying power (Sack 1983). This conceptualisation is very close to the Weberian principle of monopoly of the legitimate use of physical force. In this context, "territoriality" is understood as delineating a governance arena for the political regulation of a resource domain, which is subject to rules and to governance by one or more authorities. If institutional territories correspond traditionally to political jurisdictions, such as a commune or a nation, in the environmental field in particular, one can observe the creation of specific territories dedicated to the solving of one or more specific problems or functions (Hooghe and Marks 2003). This trend is not new, as we can identify such kinds of functional territory for many decades in the fields of urban water and urban transport management (Frey and Eichenberger 1999; Ostrom et al. 1988), as well as river basin management. However, some authors consider the creation of these kinds of territories as a worldwide phenomenon. In this context, Varone et al. (in press: 12) recently developed the concept of functional regulatory space (FRS), defining it as "a regulatory space, which politically emerges in order to tackle, support or solve problems concerning several policy sectors in different institutional territories and at different levels of government. [...] An FRS is thus a space of inextricable rivalries and conflicts, as well as a space of political regulation of these rivalries. The more or less clearly territorialised boundaries of this field of power are defined by the stakeholders who act independently from the boundaries of the pre-existing sector-specific policies and institutional territories." If the authors were to use the term "space" instead of "territory," one could understand from their definition that they consider these FRS as political spaces of regulation with territorialised boundaries, which is close to the definition of territoriality that we mentioned above.

In this paper, we propose going a step further the generic definition of a functional regulatory space (or territory) proposed by Varone et al. (in press) to analyse how different territorialities of river basin management are constructed by stakeholders and can compete. The perimeters of functional regulatory spaces are defined according to the will of actors, whether public or private, to resolve rivalries for the production of goods or services. Thus, in the domain of water, for the production of different goods and services, it is possible to observe a diversity of functional spaces (e.g. for the regulation of floods or of hydroelectricity). For the governance of a river, different types of territorialities can be observed in practice as varying with space and time, and including or excluding different kind of uses and users.

More precisely, in the field of river basin management, the spatial delineation of a FRS could vary strongly according to three dimensions.

First, the type and the number of regulated functions could vary from one type of space to another and impact the perimeter of river management structures. Governance structures at the basin scale are often firstly "the product of successful attempts to resolve collective action problems among users of a single type (e.g. urban, industrial and agricultural)" (Scholz and Stiftel 2005, 1). However, the promotion of a more integrated form of river basin management inevitably requires arbitrating between heterogeneous uses (Gerber et al. 2009; Kissling-Näf and Kuks 
2004) as well as between different and overlapping resource domains, such as water and energy or agriculture (Hering and Ingold 2012). In this context, new governance institutions could be necessary to solve multifunctional problems that occur between different types of resource uses, which are called by Scholz and Stiftel (2005) secondorder conflicts.

Secondly, the problem of boundaries definition implies the necessity of deciding which users are included or excluded from the governance structure (Hering and Ingold 2012; Nahrath et al. 2012). This is different from the first issue of multifunctionality because an FRS can manage different kinds of homogeneous or heterogeneous rivalries without opening the governance structure to a broad variety of users and stakeholders. River basin management represents a good case for studying how boundaries as well as position (understood as the physical position upstream or downstream a basin) are contested to define the new perimeters and arenas of coordination (Lebel et al. 2005).

Thirdly, the delineation of functional spaces for the management of a river can vary with the degree of involvement of public authorities. As noticed by Ostrom (1990), problems of coordination around common pool resources can be solved through collective action institutions, set directly by and between users and appropriators (Keohane and Ostrom 1995). However, the governance of large rivers and especially transboundary rivers requires involving different national jurisdictions with differentiated property rights and public policy for the management of their water resources. For Carter and Smith (2008), political jurisdictions and their boundaries need to be studied carefully because they have a strong impact on the way that public actors interpret these limits regarding their self-interest and define the problem and the nature of policy intervention and instruments. Taking into account the boundaries of political jurisdictions, especially national frontiers, the degree of involvement of public authorities from different levels is crucial for understanding the degree of autonomy (what is the room for manoeuver for actors to implement their proper rules and instruments) and of legitimacy (to what extent the FRS benefit from its proper political legitimacy regarding existing public jurisdictions and policy) of an FRS.

In a nutshell, the contributions presented in our state of the art allow us to develop an analytical framework to assess the close relationship between the spatial boundaries of the governance structure and the uses and users included or excluded from regulatory provision and governance mechanisms. To do so, we will systematically evaluate the degrees of multifunctionality, integration of different kind of users and involvement of public authorities in the governance of the river and their influence on the (re)definition of the territorial boundaries of the river's governance.

\section{Methodology}

The aim of this paper is to present the results of our study on the evolution of the uses of the river, its spatial dimension and actor configuration. It is based on two sets of data. First, we rely on a systematic analysis of the legal framework for both Switzerland and France from the end of the nineteenth century to the present. We collected and analysed all the conventions and concession contracts between local/ national authorities and public/private stakeholders, which governed the flow of the river. The analytical framework for the study of legal documents was focused on the analysis of the historical conditions of signature of the contract, its spatial extent and the types of uses taken into account and prioritised, the type of use rights and public obligations imposed to the users, the legal foundation (public or private law) of the convention or contract, and the definition of the respective role of public authorities and private actors. Second, we conducted 17 interviews with local and national authorities in Switzerland (Canton of Geneva and Vaud, Federal Office of the Environment) and France (Lyon Metropolitan Authority, Rhone Basin Agency, State's Rhone Basin Delegation), as well as with the managers of the river in the two countries (hydropower producers) and interested parties (environmental organisations). This set of interviews was systematically transcribed, formally coded by hand and analysed. The interviews were conducted following a common process in order to identify (1) which kind of convention, concession or contracts link in practice the different stakeholders, (2) how this framework concretely allows a coordination of uses among stakeholders for the main types of uses (ecosystem preservation and restoration, hydropower production, cooling of nuclear plants, production of drinking water, flood control and sediment management), (3) how upstream/downstream rivalries are managed, (4) the spatial perimeters of coordination between public and private actors and how stakeholders practically coordinate their uses within and between national territories and (5) to what extent this pre-existing governance structure is currently challenged in its content as well as in its spatial dimension. By studying the legal regime and assessing it from the point of view of stakeholders, we were able to understand how these rules and legal instruments were concretely used by actors and how they were subject to debate.

\section{From monofunctional regulatory spaces to a multifunctional and transboundary regulatory space of governance of the river}

In this fourth section, we present the three main phases of evolution of the Rhone's governance structure. Following 


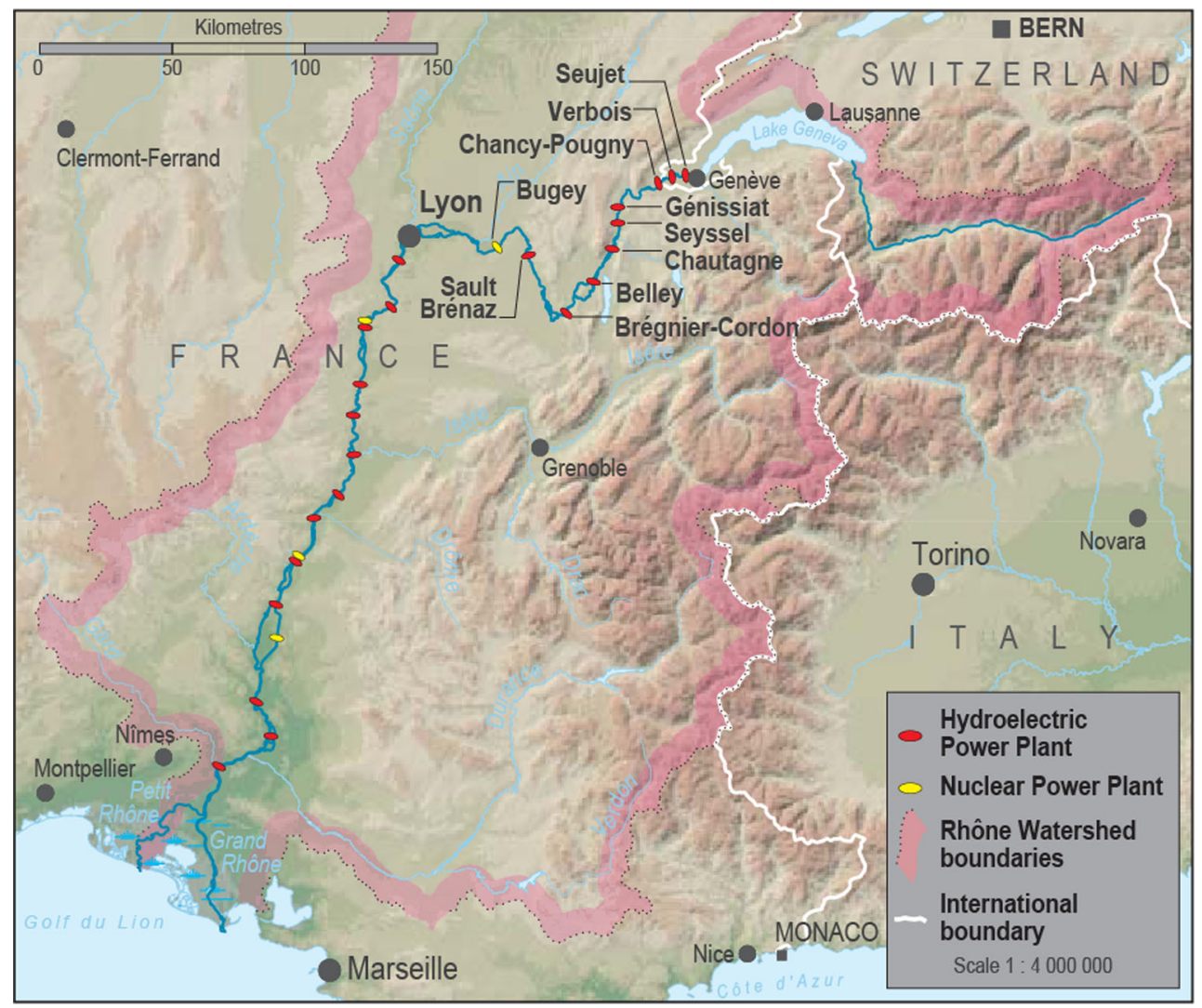

Fig. 1 Rhone river basin and main hydropower infrastructures from Geneva to Lyon (modified from GRID-UNEP 2007 and Storck et al. 2004)

our analytical framework, these different phases differ with the diverse functions and uses of the river included in the management of the river, with the main water users and actors involved in the governance procedures and with the perimeters and spatial dimension of the transboundary agreements on water.

a. Phase 1: A management of the river organised around fragmented monofunctional regulatory spaces (1870-1970)

During the first phase, occurring from the end of the nineteenth century to 1970 , national and regional public authorities prioritised a small number of water uses along the Rhone. Water was mainly used for agriculture purposes upstream from Lake Geneva. From Geneva to the Mediterranean Sea, water was primarily dedicated to hydroelectricity production (Fig. 1).

In the Canton of Geneva, the main infrastructures dedicated to the regulation of the flow of the river were built to satisfy two main objectives: the regularisation of Lake Geneva levels and the production of hydropower. At the end of the nineteenth century, the construction in the Canton of Geneva of plants able to exploit the power of water strongly modified the outflow capacities of Lake Geneva and put inhabitants and infrastructures located upstream in danger of flooding. As a result, in 1884, the cantons of Vaud, Geneva and Wallis signed an intercantonal Act for Lake Geneva water levels' regulation under the auspices of the Swiss Confederation. The Canton of Geneva built different infrastructures in 1883 and 1888, allowing for the control of water levels in order to exploit the energy produced by the water flow. The Canton of Geneva maintained the prioritisation of hydropower production until the end of the twentieth century. In 1984, the State of Geneva took the opportunity to construct a new dam able to simultaneously regulate Lake levels to protect the city from flood events and to produce hydroelectricity. The Canton delegated the use of the dam to the industrial services of Geneva (Services Industriels de Genève, SIG), a semipublic corporation providing services in the water, gas and electricity sectors. The construction of this new dam justified the delineation of a specific regulatory framework based on the intercantonal Act on the Lake levels and by management concessions for the dams of Seujet (in force since 1997) and Verbois (in force since 1996). As long as the levels of the Lake remained respected, SIG maintained a certain flexibility in implementing its exploitation strategy of the river and was able to choose when, how and how much energy to produce. Therefore, the amount of water flowing downstream from Geneva still depends firstly on 
the rules related to Lake Geneva's levels as defined by the intercantonal Act and secondly on the hydropower production policy of SIG. Concretely, this means, for example, that levels of the Rhone downstream from Geneva will be dependent on the evolution of electricity consumption in Geneva. Hydropower remains dominant compared to other types of water uses, such as the natural functioning of ecosystems for example.

Downstream from Geneva, the Compagnie Nationale $d u$ Rhône (CNR), manages the French part of the Rhone and holds a concession contract for the management of the river from the Swiss border to the Mediterranean Sea. According to this concession contract, ratified in 1934 for 99 years, the CNR has three major objectives: production of electricity (19 hydropower plants), navigation (downstream from Lyon) and water supply for irrigation. The French concession integrates different types of water uses. If the main concern was firstly to better manage floods events, then hydropower quickly became the main goal of the central State. In a post-WWII context, France invested heavily in the Rhone River's industrialisation, which was considered by the state as a symbol of the French nation's reconstruction. As shown by Pritchard (2011), the Marshall Plan benefited from massive investments (2010: 70): “The CNR received almost 2 per cent of all Marshall Plan funds distributed in France between 1948 and 1951." As a consequence, the French state chose to heavily embank the Rhone along its entire course, and the production of hydroelectricity became the main use of the Rhone's water. The sentence, "Le Rhône au service de la Nation," written on one of the main monuments of French infrastructure (the dam of Seyssel) illustrates the prioritisation of the productive use of the Rhone, which is considered less as a hydrosystem than as an industrial tool to produce energy (Pritchard 2011).

During this first phase, the regulatory spaces for the governance of the river were strongly fragmented. Despite different attempts to collaborate, there was no transboundary regulation framework between France and Switzerland. The only existing agreements concerned exchanges of water related to hydroelectricity and some punctual procedures to monitor sediment discharge. Hydropower producers developed instruments of coordination at a transboundary scale without involving public authorities. According to the SIG responsible for electricity production, "SIG implement a programme of production defined for several forthcoming days. This programme is communicated to CNR who is able to modulate water incomes with the storage capacities of Génissiat dam" (18 July 201, Geneva, our translation).

During this phase, public authorities did not consider the transboundary scale of governance of the river basin as a pertinent space of regulation, although the French water law (promulgated in 1964 and partly influenced by the creation of the CNR in 1921, as mentioned by Ghiotti 2006: 10) called for water management through such type of regulatory space. Therefore, the transboundary governance of the Rhone River remained fragmented and bordered by national frontiers. This fragmentation was also linked to the weak involvement of public authorities in the management of the river beyond their regulatory responsibility and the concession contracts signed with private operators on each side of the border.

b. Phase 2: The consolidation of multifunctional regulatory spaces and transboundary coordination (19702000)

Since the seventies, the growth of nuclear production and the new role of public administrations in the field of environmental preservation have pushed public authorities to open up the monofunctional regulation of the river to new uses and users. However, while the governance of the Rhone differs strongly between Switzerland and France, it is still centred on power production on both sides of the border (see Fig. 2).

In France, a new type of operator became involved in the governance of the Rhone. The CNR now had to negotiate and collaborate with Electricité de France $(E D F)$, which is managing all the nuclear plants along the river. The CNR lost its monopoly position as the central State decided to prioritise a share of water flow to ensure the cooling of nuclear plants and navigation downstream from Lyon. Thus, nuclear security became a key issue of the transboundary management of water transfers between Switzerland and France. The emergence of a new major water user increased rivalries and called for the implementation of specific regulatory arrangements. The CNR, unique manager of the river and holder of the concession contract from the State, signed different types of agreements (or sometimes contracts) with the other private actors making use of the river with EDF in France and with SIG in Switzerland. If public authorities such as the French Rhone Basin Agency, the Region Rhone-Alpes and the Rhone Basin Delegation of the central state participate in the governance structure by defining regulations and monitoring the concession contracts, then their role will remain limited on an operational level and will leave a good deal of room for manoeuvre to private operators. Even if hydroelectricity remains the main use of water, the Rhone progressively became a multifunctional object involving a growing but still limited number of users. The management of rivalries essentially depends on private law agreements between electricity producers. As mentioned by the head of the service "pressure on hydrosystems" at the Rhone Basin Delegation of the central State, " $(\ldots)$ the management of water flows at the outlet of Lake Geneva 
Fig. 2 Governance structure and actors configuration of the Rhone

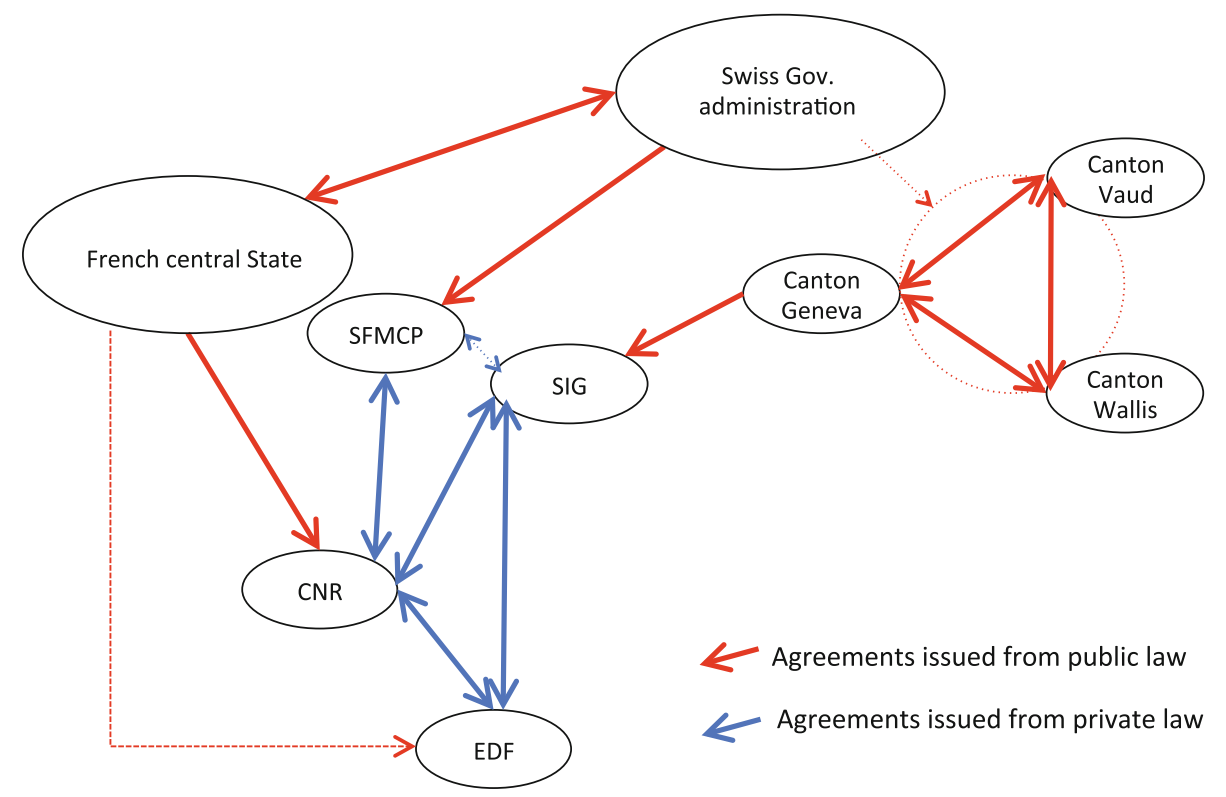

results from more or less elaborated, or more or less constraining arrangements between CNR and SIG" (10 July 2012, Lyon, our translation). Thus, this operational governance structure of the French part of the Rhone tends to exclude actors that are not involved in a productive relationship with the Rhone. This is particularly the case with environmental NGOs or the communes located along the banks of the river.

On the Swiss side of the border, the regulation of the river essentially depends on two types of legislative documents. As we already saw, the first one is the convention concerning the regulation of Lake Geneva's levels dating from 1884 (renewed in 1984). The second one is a set of concession contracts signed between the canton of Geneva or the Swiss government and the SIG, resulting from a long-lasting relationship between the canton of Geneva and the semipublic electricity company (Paquier and Pflieger 2008). The Swiss part of the Rhone River is thus managed through agreements depending on public law with the strong involvement of public actors responsible for the monitoring of concession contracts. Within this legal framework, hydroelectricity has a major role to play in the Rhone River management as the concession contracts evolved regularly to include new objectives such as flood protection or ecosystem management of the river and its banks (for example, operators are responsible for fish transit or the ecological restoration of some river's sections) (Delahay 2009). In the Swiss section of the Rhone, this second phase is characterised by the increase in water uses effectively taken into account in the concession contracts. Historically, public authorities were mainly concerned with flooding and hydropower production, but new types of considerations related to the protection of the environment are now integrated in the regulatory framework. Nevertheless, as mentioned, the production of hydroelectricity remains the dominant use of the Rhone, and ecological measures are mainly implemented through the concession contracts signed by the hydropower producer.

Between France and Switzerland, the transboundary coordination was strengthened but remained focused on hydropower and operational issues. In 1963, France and Switzerland decided to build the Dam of Emosson in the canton of Wallis. As the dam was withdrawing water from the Arve river basin located in France, Switzerland agreed to return the collected and valued water at the outlet of the Rhone in Geneva. As a result of this agreement, France holds a stock of water in Lake Geneva representing 85 million cubic meters of water available yearly. This stock can be claimed at any time and for any use decided upon by the French government (as previously discussed, until now the priority has been on navigation and the cooling of nuclear plants). A convention (Mesures d'exécution 2000) between the different operators (SIG, CNR and EDF) defines the conditions of water transfer downstream from Geneva. The mesures d'exécution 2000 is the only collaborative entity in existence for managing the Rhone in a transboundary perspective. It materialises the implementation of a regulatory space dedicated primarily to the governance of energy production (nuclear energy or hydroelectricity) and the resolution of upstream-downstream homogeneous rivalries. However, by doing so, the mesures d'exécution 2000 convention interconnects two geographical spaces separated by Lake Geneva. It redefines political boundaries on the basis of a multifunctional arrangement related to water rights originally granted to 
hydroelectricity producers. The convention "mesures d'exécution 2000" concerns the coordination between hydropower operators and aims at defining the amount of water necessary for irrigation, industry, the production of drinking water and the conservation of ecosystems during periods of water scarcity.

The second phase of Rhone River governance sees the emergence of transboundary and multifunctional agreements on the Rhone. The collaboration between Switzerland and France regarding the management of the river is not based on any international convention or commission (which is the case in other major European river basins). The functional regulatory spaces seem less fragmented even if the transboundary collaboration remains focused on the functioning of one sector: the collaboration between the two countries (and more specifically the exchange of water) relies on the energy sector.

c. Phase 3: The emergence of a multifunctional and transnational space of regulation (2000-ongoing)

As illustrated in phase 2, the governance structure of the river remains organised on a sectorial basis around the production of electricity. However, since the early 2000s, these functional spaces have been confronted by an increase in water management complexity due to the growing amount of uses, which were not previously recognised.

These new water management policies follow the reinforcement of environmental legislation in Switzerland, France and the European Union, which have rapidly been orientated towards the river basin unit and on a better protection of ecosystems. In France, public authorities took several timely measures to reinforce ecosystem preservation of the Rhone through the ecological restoration of several sections of the river. The legal framework evolved quite recently to better integrate ecosystem uses of water and to a regulate the river as part of a biodiverse network. The main regulations emerged between 2006 and 2010 (for example, la Loi sur les milieux aquatiques in 2006 and la Loi Grenelle II in 2010), mainly resulting from the evolution of European Union's legal framework. The legal framework tends to constrain hydroelectricity producers from taking new types of water uses (ecosystemic services, for example) into account. This is particularly the case with the implementation of the European Water Framework Directive (Directive 2000/60/EC) and the different national legal norms depending on it. Thus, the growing intervention of the public sector within the configuration of actors illustrates this transfer of priority setting regarding the uses of the Rhone River. Production of hydroelectricity tends to be more precisely framed by policy instruments (Schéma Directeur d'Aménagement et de Gestion des Eaux: $S D A G E$ ), and public actors (the French Rhone Basin Agency) aim to increase the coherence of water management within French borders. Therefore, the increase in heterogenous uses and related potential rivalries, and the development of legal frameworks imply a return of central States to the centre of the stage. While the self-management of private actors proved its efficiency in operating the river until the 2000s, the shift to the inclusion of new water uses and users calls for the stronger involvement of public actors in order to resolve complex priority setting and heterogenous rivalries between uses. This is especially true when the resource is shared in a transboundary way between two countries.

The case of the transboundary management of the sediment discharge of hydropower dams illustrates this shift particularly well. Close to the border between Switzerland and France, the dam of Verbois, located in Switzerland, must periodically discharge its sediment. This operation has been undertaken regularly since the construction of the dam, but was mainly dependent on the collaboration between the two operators (SIG and CNR) and was realised without any in-depth discussions. In 2012, however, the discharge was characterised by increasing administrative complexity, wherein a 3 year period of public enquiry and the establishment of an authorisation on a transboundary scale were required. Hydropower operators lead the whole procedure under the auspices of public authorities (the central State in France and the Canton of Geneva in Switzerland), which are now strongly involved in the monitoring of the whole process. This case exemplifies the current changes in the governance structure of the river. The involvement of public authorities strongly increased in recent times, along with the regulatory framework, leading to greater complexity for such a procedure. This complexity is well illustrated by the Director of Geneva's Canton water service: "for example, in France, CNR has been the unique manager of the French Rhone for a long time. Today, the granting of concession is not guaranteed anymore. It will be more complicated. This is not only a French problem but a Swiss problem too. The more you get stakeholders involved, the more it becomes complicated" (17 July 2012, Geneva, our translation). This is especially the case with the Rhone, as the river basin scale is divided by national boundaries and public authorities suffer from weak policy instruments for managing water in a transboundary way. As mentioned by the General Secretary of Geneva's Canton Department of the Interior, Mobility and the Environment, "The institutional framework is weak on the Swiss side. Therefore, we created a group able to reinforce the existing institutional framework and to answer to the problem of coherence between two very different institutional frameworks" (23 April 2013, Geneva, our translation).

During the third phase, the spatial extension of the regulatory framework is quite similar to that of phase two. 
Table 1 Evolution of Rhone River governance between 1870 and today

\begin{tabular}{|c|c|c|c|c|}
\hline & $\begin{array}{l}\text { Mono/ } \\
\text { multifunctional } \\
\text { regulations }\end{array}$ & Included/excluded users & $\begin{array}{l}\text { Private or public actors } \\
\text { involvement }\end{array}$ & Spatiality \\
\hline $\begin{array}{l}\text { Phase } 1 \\
\quad 1870-1970\end{array}$ & $\begin{array}{l}\text { Monofunctional } \\
\text { regulation }\end{array}$ & $\begin{array}{l}\text { Included: hydroelectricity producers } \\
\text { Excluded: environmental } \\
\text { organisations } \\
\text { Absent: nuclear energy producer }\end{array}$ & $\begin{array}{l}\text { Switzerland: public actors as } \\
\text { manager and regulator } \\
\text { France: private actors and self- } \\
\text { management }\end{array}$ & $\begin{array}{l}\text { Management at the basin } \\
\text { scale in France only } \\
\text { (through CNR } \\
\text { concession) no } \\
\text { transboundary agreements }\end{array}$ \\
\hline $\begin{array}{l}\text { Phase } 2 \\
\quad 1970-2000\end{array}$ & $\begin{array}{l}\text { Multifunctional } \\
\text { regulation of few } \\
\text { water uses }\end{array}$ & $\begin{array}{l}\text { Included: hydroelectricity producers } \\
\text { nuclear energy producer } \\
\text { Excluded (but emerging): public } \\
\text { administrations responsible for } \\
\text { environmental preservation }\end{array}$ & $\begin{array}{l}\text { Switzerland: public actors as } \\
\text { regulator/semipublic actors as } \\
\text { manager } \\
\text { France: on a sectorial basis private } \\
\text { actors and self-management }\end{array}$ & $\begin{array}{l}\text { Transboundary agreements } \\
\text { existing on a sectorial } \\
\text { basis }\end{array}$ \\
\hline $\begin{array}{l}\text { Phase } 3 \\
\text { 2000-ongoing }\end{array}$ & $\begin{array}{l}\text { Multifunctional } \\
\text { regulation of } \\
\text { heterogeneous } \\
\text { and complex } \\
\text { rivalries }\end{array}$ & $\begin{array}{l}\text { Included: hydroelectricity producers } \\
\text { nuclear energy producers public } \\
\text { administrations in charge of } \\
\text { environmental preservation } \\
\text { Excluded (but emerging): } \\
\text { environmental organisations }\end{array}$ & $\begin{array}{l}\text { Switzerland: public actors as } \\
\text { regulator and manager (for } \\
\text { environmental issues)/ } \\
\text { semipublic actors as manager } \\
\text { France: private actors as manager/ } \\
\text { public actors with reinforced } \\
\text { regulatory power in energy and } \\
\text { environmental fields }\end{array}$ & $\begin{array}{l}\text { Attempt to define new } \\
\text { transboundary } \\
\text { institutional mechanisms } \\
\text { between public authorities }\end{array}$ \\
\hline
\end{tabular}

However, central States, regarding their respective political agendas and jurisdictional obligations (for example, France has to reach specific environmental norms imposed by European Union's Water Framework Directive), are currently trying to find new institutional mechanisms that are able to better frame transboundary governance of the river through negotiations at a high political level, contrasting with the self-management procedures and arrangements between private actors that were prevailing during the previous phase.

\section{Discussion}

In this article, we analysed the governance structure of the Rhone through the lenses of an analytical framework composed of four interrelated dimensions: mono/multifunctional regulations, inclusion/exclusion of uses and users, involvement of private or public actors and their relations with the territoriality of river management (see Table 1).

To conclude this paper, we aim to discuss these results by answering our three research questions:

1. How have the territorialities of river management evolved since the nineteenth century?

Through the description of the three different phases of river governance, we demonstrated that the territoriality of river management tends to evolve in an incremental way from monofunctional spaces of regulation to a multifunctional and transboundary regulatory space at the river basin scale, in line with the integrated water resource management concept. The management of the river remained firstly limited to the national boundaries. Then, private actors implemented several transboundary agreements, which remained mainly dependent on the hydroelectric sector and on self-management and arrangements between private actors. Finally, public actors try today to define new institutional mechanisms able to overcome national boundaries well beyond the operational coordination between hydropower producers. The shift in the territorialities of river governance is strongly influenced by the emergence of new uses and heterogeneous rivalries, which are leading to a multifunctional regulation of the river. This is especially the case when new uses have a potential impact on a wider scale and across national boundaries. For example, the use of the Rhone to cool nuclear power plants is a major issue, as an accident at the nuclear power plant of Bugey, located $35 \mathrm{~km}$ away from Lyon and $110 \mathrm{~km}$ from Geneva, would have an impact on both France and Switzerland.

2. What is the impact of these various territorialities on uses and users, both in terms of inclusion and exclusion?

As we have seen, the evolution of river governance territoriality impacts the integration of different uses. The first phase was characterised by a monofunctional regulation organised between different but interconnected regulatory spaces, with one main type of use included in the governance structure: hydroelectricity production. During the second phase, public and private actors modified the 
regulatory framework and arrangements to arbitrate between nuclear and hydroelectric uses of the river. The third phase is characterised by the multifunctional regulation of heterogeneous and complex rivalries. As we have observed, national and local authorities progressively integrated and legitimised new water uses within the spaces of regulation, such as environmental and ecosystem preservation. They called upon hydropower producers to take into account these unrecognised uses in their management of the river through the modification of regulatory frameworks and through new requirements in concession contracts. Thus, since the early 2000s, the implementation of a new political agenda in relation to IWRM has tended to reinforce, on the one hand, the inclusion of heterogeneous uses and rivalries among users and, on the other hand, to manage the interdependencies between the upstream and downstream parts of the river.

3. Reciprocally, to what extent has the emergence of new uses, and users, challenged the territorial governance of the river?

The inclusion of new water uses had a large impact on the governance of the river. Describing the three phases of the Rhone's governance, we have observed the increase in heterogeneous rivalries through the inclusion of new water uses driven by the local and national public authorities. During the third phase in particular, public authorities began to consider that the diverse multifunctional spaces that were still bordered on national territories were no longer sufficient for managing such complex and heterogeneous rivalries. This third phase illustrates a need for greater responsibility of the public sector within the governance structure of the river and therefore the attempt of public authorities to redefine a common political regulatory space through a new transboundary perimeter. Thus, while the self-organisation of private actors is still present during the third phase, public authorities seem to always get more involved by deciding (and sometimes imposing) the uses to prioritise. In this context, the transboundary scale tends be imposed not only as an operational space but also as a new political arena characterised by the confrontation of different political agendas and regulatory framework objectives. Thus, changes in territorialities occurred under the pressure of the emergence of more and more heterogeneous uses, which required that the role of public authorities be strengthened. In the current phase, the coordination between complex uses pushed public authorities to build a new transboundary and political space of regulation.

Using the case of the Rhone, we have demonstrated that the redefinition of the territoriality of river governance induces power games between actors at different scales and intersectoral tensions and rivalries. The role played by hydropower operators and then by public authorities shows that different kinds of territoriality (sometimes going beyond national boundaries) could exist to manage a river. While public actors today tend to push IWRM forward, the historical governance structure of the Rhone River illustrates how agreements mainly orientated towards the functioning of one sector of activity avoided the implementation of strong regulations at the river basin scale.

However, we demonstrate in the third phase that the institutional setting evolves to more complexity with an increasing number of actors involved, a blurring of the roles and functions, multiple scales of intervention and a number of overlapping initiatives from different institutional levels, which sometimes target similar objectives. Therefore, looking at the evolution of the governance structure, we propose to consider that the coherence of the management of the river (and subsequently its level of integration) can potentially be diminished during the actual phase of governance. On the basis of these elements, one can question the concept of IWRM. Our analytical variables show that an increased cooperation between actors, the consideration of the river basin scale of governance and the inclusion of a growing number of water uses do not necessarily lead to more integrated and coherent management of the river. In this sense, the upcoming renegotiation of French Rhone concession contract represents a great opportunity to the central State to define new institutional arrangements able to better integrate ecosystemic uses of the river and to implement transboundary management of the Rhone.

Acknowledgments This article is the result of data collected for the research project "GOUVRHONE, hydropower and the regulation of the Rhone River in a context of climate change and electricity liberalisation" led by the University of Geneva within the Institute of Environmental Sciences (Group Politics, Environment and Territories). The project started in May 2012 for a period of 36 months and is funded by the French ministry of ecology, the French water Agency Rhône Méditerranée and Corse, the Swiss federal office for the environment, the cantons of Geneva and Vaud, Services Industriels de Genève (SIG) and Electricité de France (EDF).

\section{References}

Barraqué B (2001) Les enjeux de la directive cadre sur l'eau de l'Union européenne. Flux 46:70-75

Barraqué B (2009) The development of water services in Europe: from diversity to convergence? In: Castro JE, Heller L (eds) Water and sanitation services: public policy and management. Earthscan, Londres

Brenner N (2004) New state spaces: urban governance and the rescaling of statehood. Oxford University Press, Oxford

Carter C, Smith A (2008) Revitalizing public policy approaches to the EU: 'territorial institutionalism', fisheries and wine. J Eur Public Policy 15(2):263-281

Delahay E (2009) Les espaces fluvio-urbains rhodaniens à l'aval de Lyon, Vienne, Valence, Avignon, Tarascon, Beaucaire et Arles: des territoires à la dérive? Phd Thesis, Université Lumière Lyon 2 
Frey BS, Eichenberger R (1999) The new democratic federalism for Europe: functional, overlapping, and competing jurisdictions. Edward Elgar

Gerber J-D, Knoepfel P, Nahrath S, Varone F (2009) Institutional resource regimes: towards sustainability through the combination of property-rights theory and policy analysis. Ecol Econ 68(3):798-809

Ghiotti S (2006) Les Territoires de l'eau et la décentralisation. La gouvernance de bassin versant ou les limites d'une évidence, Développement durable et territoires (On line), Dossier 612006, on line the 10 February 2006, consulted the 04 June 2013. http:// developpementdurable.revues.org/1742; doi:10.4000/developpe mentdurable. 1742

Graefe O (2011) River basins as new environmental regions? The depolitization of water management. Procedia Soc Behav Sci $14: 24-27$

Hering JG, Ingold MK (2012) Water resources management: what should be integrated? Science 336(6086):1234-1235

Hooghe L, Marks G (2003) Unraveling the central state, but how? Types of multi-level governance. Am Political Sci Rev 97(2):233-243

Keohane R, Ostrom E (eds) (1995) Local commons and global interdependence. Sage, London

Kissling-Näf I, Kuks S (eds) (2004) The evolution of national water regimes in Europe. Kluwer, Dodrecht

Lebel L, Garden P, Imamura M (2005) The politics of scale, position, and place in the governance of water resources in the Mekong Region. Ecol Soc 10(2):18. http://digitalcommons.usu.edu/unf_ research $/ 32 /$

Moss T (2003) Solving problems of 'fit' at the expense of problems of 'interplay'? The spatial reorganisation of water management following the EU water framework directive. In: Engels A, Breit $\mathrm{H}$, Moss T, Troja M (eds) How institutions change. Perspectives on social learning in global and local environmental contexts. Leske + Budrich, Opladen

Moss T, Jens N (2010) Multilevel water governance and problems of scale: setting the stage for a broader debate. Environ Manag 46(1): $1-6$

Nahrath S, Varone F, Gerber J-D (2009) Les espaces fonctionnels : nouveau référentiel de la gestion durable des ressources? VertigO 9(1):1-14

Nahrath S, Gerber J-D, Knoepfel P, Bréthaut C (2012) Le rôle des institutions de gestion communautaire de ressources dans les politiques environnementales et d'ames institu du territoire en Suisse. Nat Sci Société (NSS) 20:39-51

Ostrom E (1990) Governing the commons, the evolution of institutions for collective action. Cambridge University Press, Cambridge

Ostrom E (1999) Revisiting the commons: local lessons, global challenges. Science 284(5412):278-282

Ostrom E (2010) Polycentric systems for coping with collective action and global environmental change. Glob Environ Chang 20(4):550-557

Ostrom V, Robert LB, Ostrom E (1988) Local government in the United States. ICS Press, San Francisco

Paquier S, Pflieger G (2008) L'eau et les services industriels de Genève : aux origines du modèle suisse des services urbains. Entreprises et Histoire 50:36-51

Pritchard SB (2011) Confluence: the nature of technology and the remaking of the Rhone (No. 172). Harvard University Press, Harvard

Sack RD (1983) Human territoriality: a theory. Ann Assoc Am Geogr 73(1):55-74

Scholz J, Stiftel B (eds) (2005) Adaptive governance and water conflict. Resources for the future, Washington DC

Storck F, Pochat M, Tosello F (2004) Utilisation des outils Arcveiw 3D-Tracking Analys pour l'étude de l'aléa inondation induit par les crues du Rhône et de la Saône sur le territoire du Grand Lyon. Unpublished paper presented at SIG 2004, conférence francphone ESRI, Issy-Les-Loulineaux

Swyngedouw E (2004) Scaled geographies. Nature, place, and the politics of scale. In: McMaster R, Sheppard E (eds) Scale and geographic inquiry: nature, society and method. Blackwell, Oxford

UNEP-GRID Geneva. n.d. Rhone basin [Map], Retrieved July 24, 2013, from: http://www.grid.unep.ch/index.php?option=com content $\&$ view $=$ article $\&$ id $=73 \&$ Itemid $=400 \&$ lang=en $\&$ project id $=25$ FE 9290

Varone F, Nahrath S, Aubin D, Gerber J-D (in press) Functional regulatory spaces. Policy Sciences. http://link.springer.com/ article/10.1007\%2Fs11077-013-9174-1, doi:10.1007/s11077-0139174-1

Young OR (2002) The institutional dimensions of environmental change: fit, interplay, and scale (global environmental accords: strategies for sustainability). MIT Press, Cumberland 